\title{
RELEVANCE OF ACCOUNTING INFORMATION TO PUBLIC SECTOR ACCOUNTABILITY: A STUDY OF BRAZILIAN FEDERAL PUBLIC UNIVERSITIES
}

\begin{abstract}
Public Sector Accounting is particularly relevant in the context of New Public Management because it is the most important approach for recording and reporting management acts, helping public managers to achieve their objectives regarding internal and external reporting for accountability purposes.

This study main objective is to evaluate the usefulness of accounting information as well as the findings of non compliance in the opinions of audits conducted by Internal Control System in explaining the quality of 51 Brazilian federal universities, using data from the General Index of Courses published in 2007.

The findings demonstrate that accounting information of the Brazilian federal universities, particularly current expenses and operating assets are significant to explain the quality index reached by the HEIs, endorsing the relevance of accounting to accountability, considering the diverse stakeholders. The evidence also reveals that qualifications in audit opinions are not relevant to explain the universities performance.
\end{abstract}

The findings may assist as criteria for formulating public policies on resource allocation in education, and also contribute to improve auditing systems in the Internal and External Control of the Education Sector.

Keywords: Accountability, Public Sector Accounting, Educational Quality, Higher Education. 


\section{INTRODUCTION}

The development of democracy and the establishment of liberal thought contributed to apply in public administration methodologies focused on the economy, efficiency and effectiveness in public services management, in order to maximize the benefits for citizens considering the resources available.

This new approach of public services management is the so called New Public Management movement that introduced methods and concepts into the Public Sector Administration inspired on business sector management practices and assumptions.

To reach these changes, the adoption of the accountability concept is crucial since it requires Public Administration to be transparent and informative, and managers to be responsible for both the results obtained and the resources used. It is therefore necessary to look for specific tools that may assess the public services management highlighting management performance and ensure managers' accountability.

In this context, Public Sector Accounting assumes particular importance as it represents the main tool for recording and reporting management activities information; it contributes significantly to the fulfilment of public management objectives on internal and external reporting for accountability purposes.

This study is focused on Brazil and analyses the financial statements of the public federal universities to assess whether they provide relevant information that explains the performance achieved by these entities. It also aims to find out if their outcomes are affected by findings of non-compliance audits carried out by the Internal Control System bodies.

Two questions were formulated to meet the above mention purposes: i) Is the accounting information provided by universities useful to the accountability process in terms of performance and does it helps to explain the Brazilian Federal Universities performance in the quality ratings they are submitted? And (ii) Do the findings of non-compliance in audits influence the Brazilian Federal Universities performance in the quality ratings that are submitted?

To answer these questions, the paper is organized into five sections, including this Introduction. The second section discusses the emergence of the New Public Management movement, relating it with the concept of accountability. It also deals with the accounting role for accountability, including the approach of international accounting standards appropriate to the public sector; the key reforms in Public Accounting in Brazil under this context are also highlighted. Section three addresses the problems of measuring quality in public entities, including the assessment of higher education in Brazil. The empirical study is presented in section four, focused on analysing the relationship between the quality index, accounting information and audit findings for the universe of Brazilian federal universities, considering its General Index of Courses (GIC) released in 2007. This section highlights the methods and data used in the research, specifying the models used and defining implicit variables. Finally, the main conclusions are presented in section five, including some proposals about the possible usefulness of the findings .

\section{NEW PUBLIC MANAGEMENT, ACCOUNTABILITY AND ACCOUNTING}

\subsection{New Public Management and the State Reform in the late twenty century}

The last 20 years of the 20th century were marked by a reform movement called New Public Management (NPM) aimed at understanding and managing public sector activities. It required breaking with the bureaucratic model and introducing concepts into Public Sector Administration such as competitiveness, efficiency and performance that were already in currently use in the private sector management.

According to Hood (1995) the main features of the NPM movement can be summarized as follows:

- Unbundling of the Public Sector into corporatized units organized by product;

- Need to apply recognized private sector management tools in the public sector; 
- Necessity to look at discipline and frugality use of resources;

- Accountability requires clear assignment of responsibility, not diffusion of power;

- Need for explicit formal measurable standards and measures of performance

- Accountability means clearly quantified aims;

- Efficiency needs firm look at goals

- Emphasis on inputs and outputs controls and efficiency focused on outcomes.

According to Bresser-Pereira (2000), Brazil was a pioneer among developing countries when it adopted the NPM theories in 1995; these emerged within a broader process searching to modify the management of public activities and implement a structural reform in the Brazilian State. This reform included three dimensions: institutional, cultural, and reliable management. According to this author:

- Institutional reform involved creating new legal institutions that would bring modern and professional conditions to an organizational structure to manage the state;

- Cultural reform meant definitively abandoning patrimonial practices when conducting public affairs, and changing from a bureaucratic culture focusing on processes, to a management cultural focusing on the citizen-customer;

- Management reform is linked to NPM implementation and refers to the adoption of new management tools that provide better public services for the citizen-customer at the lowest possible cost.

In Brazil the State Reform embraces new control systems. According to the current Brazilian Constitution, the supervision and control of Public Administration is conducted externally, namely by Parliament with the support of the Court of Auditors and their respective Internal Control.

Among the many powers of the Court of Audit laid down by the Constitution and the Organic Law of the Court (Law No. 8 443/92), special note goes to the assessment of the accounts rendered annually by the President to Parliament; this is a macro-assessment of government action evaluating resources allocation.

Internal control in the Federal Executive Branch is regulated by Decree No. 3.591/2000 and is organized on two levels. The first level concerns the direct responsibility of public administration agencies and entities. The second level of control respects the Internal Control System of the Federal Executive and is made up of General Controller of the Union - CGU (body with ministerial status), as well the Central Organ and the departmental bodies in the Presidency of the Republic, the Attorney General's Office, Ministry of Foreign Affairs and the Ministry of Defence.

The institutionalization of specific bodies of Internal Control in the state structure provides them a more active and comprehensive control of public accounts; their currently responsibilities include promoting audits (primarily compliance) in the Public Administration bodies and entities whose certificates will comprise the formal accounts processes that are involved for trial by the Court.

According to the Manual of Internal Control System of the Executive Branch (2001) applicable to all bodies, services and agencies of the federal government, including public universities, the audits carried out by Federal Office of Internal Control are classified according to their purpose as: Management Assessment Audit, Management Monitoring Audit, Audit of Financial Statements; Operational Audit and Special Audit.

The manager's process of rendering of accounts to the Supreme Audit Institutions requires a certificate issued by the Internal Control System opining about the regularity of the management in several aspects. Those certificates are delivered on a Management Assessment Audit which aims to examine the regularity of the accounts by verifying contracts, integrity in the application of resources, considering how public money and other assets are administrated.

In this auditing (Management Assessment Audit), the following items, among others, are examined: check all the documents that entities are obliged to introduce in the rendering of accounts process; examination of supporting documents related to administrative acts and proceedings; analysis of the efficiency of the administrative and accounting controls; verification of compliance with relevant legislation; and evaluation of 
operational results and government programs implementation regarding the economy, efficiency and effectiveness perspectives. Data from these certificates assessing accounts regularity, or not, will be used as a source in this study

\subsection{Accountability and Accounting}

The need to reinforce governance and state governance was a recurring issue during the introduction of NPM in Latin America (CLAD, 1998) and, according to Sarker (2009), accountability is a key feature of good governance and one of the foundations of democracy. The term has no direct translation in Portuguese but it is crucial to comprehend its broad meaning so that we can define the factors and conditions necessary to implement the concept.

This involves exposing the exercise of power to the menace of consents, it requires power to be exercised in a transparent manner and that people with this power should justify their actions (Schedler, 1999). Thus, this author argues that accountability must occur in two dimensions in order to be effective: its coercion ability (enforcement) and its ability to respond to the beneficiaries of accountability (answerability).

Lapsley (2008) explains that the management process of which accountability is a key element is the heart of NPM and thus implies high standards of transparency and accountability with serious consequences for public managers; this highlights the relevance of the coercive nature (enforcement) of accountability.

Besides emphasizing the importance of accountability in the management process, NPM indicates that it should focus on management performance (outputs) and not only on the means used (inputs) as had previously occurred (Hood, 1995; Jansen, 2008).

This change in focus in accountability requires monitoring bodies to play an important role given the influence of their actions on management and public policies (Barzelay, 1996; Sharkansky, 2007); indeed, the idea of management by objectives is not new and can be found in the conceptual evolution of public budgets notably since the middle twentieth century (Giacomoni, 2008, Lee et al. 2004). One of the reasons for not implementing management by objectives is that, despite budgetary change, the control of management by the competent bodies continued to be focused on the means.

As COSO (1992) defines the objectives of internal control framework concerned with the citizens imply that application of public resources must be demonstrated in a transparent and reliable way, according to the laws and regulations and, especially, reaching the goals for which resources were allocated. For these reasons the doctrine of NPM emphasizes transparency and control concentrated on results and it sees the citizen as a customer.

To be able to assess these aspects it is necessary to have reliable accounting systems, audit bodies and adequate methodologies for evaluating public policies and services available to citizens. So it is crucial to show the relationship between accountability, accounting and public services evaluation, namely the quality of public higher education offered by public universities in Brazil, the object of this study.

Accountability involves justifying actions so that management facts and results are clarified (storytelling) and the consequent managers' responsibility for their actions. Accounting is the language used and the way this story is recorded so that it can be told (Porter and Norton, 2007); Financial Statements as an Accounting output are already a relevant part of that story.

If in the private companies their intrinsic value is given by the share price, in public sector the value generated depends on society's perception regarding the importance of goods or services provided, and that perception can not be translated into monetary terms as in business oriented entities (Moore, 1996). So, alternative measures must be found to represent the value formation and performance in public sector entities; in this study quality has been chosen as it. 
The NPM changes relating to targets and how to drive the public organization also affected public accounting in both finance and management. Ter Bogt (2008:213) states that the introduction of NPM or related management systems "can be considered a change in control systems for managing public sector organizations", so the changes required by NPM affect their accounting systems.

Following the trend of Business Accounting, efforts have also been made to promote harmonization in the Public Sector Accounting standards, notably by the International Federation of Accountants - IFAC through the Committee for the Public Sector now renamed the International Public Sector Accounting Standards Board (IPSASB); according to Jesus (2010: 36), it "has been the international body which has shown real commitment to accounting harmonization in the sphere of Public Sector Accounting, through a process of normalization - emission of standards, the International Public Sector Accounting Standards ( IPSASs), which underlies the need for public sector providing better quality financial information. "

However, there are still very dissimilar practices in the public sector as the public sector accounting system generally seeks to respond to each country's specific needs (Jesus, 2010). Thus, international harmonization recognizes exclusive political and administrative specificities and aims to provide guidelines to be followed, allowing the necessary adjustments for its implementation (IPSASB, 2009). This flexibility is no longer found in the private sector and the term international harmonization, which includes the accommodation of local differences (the "one size fits all" approach), is no longer considered adequate; it has gradually been replaced by international convergence (using the ADOPT BUT DO NOT ADAPT approach), which strives for common comparable outputs (Weffort 2005).

\subsection{Public Accounting Reforms in Brazil}

As detailed in section 2.1, Brazil developed several reforms in the State Administration, but not necessarily in Public Sector Accounting. As Christensen and Lægreid (2005) explain that administrative reforms should contemplate the context of the country since different countries have different economic, political and social starting points. This is evident in the Brazilian case in which the deployment of New Public Management from 1995 to 2000 did not introduce significant changes in accounting, unlike many countries.

Nunes (2007) argues that the Fiscal Responsibility Law enacted in 2000 required a Brazilian Public Accounting more oriented to patrimonial aspects than to the budget, although few changes were actually implemented; the framework approved in the 1960s still remain and, according to Niyama and Silva (2008), it is focused only how to do things, not considering theoretical developments in its design.

The interpretation and comparison of Financial Statements for Brazilian Public Sector entities may be difficult since Brazilian legislation, applicable when this study was carried out, does not provide criteria for assets and liabilities recognition and measurement and shows a lack of concepts (Lima et al., 2009).

In fact, only one article in Law 4.320 / 64 address the issue of assets and liabilities measurement and it is very simplistic. Due to omissions in the law, depreciations and asset impairments and their respective costs are not recognized; periodic review or elimination at the end of their useful life is the only possibility, which prejudices the use of accrual basis. Moreover, the public assets of common use are also not recognized even when they carry out future economic benefits or service potential.

In the case of equity changes, the criteria are presented in a mixed approach depending on the type of variation observed. Traditional Brazilian doctrine states that the mixed regime adopted by public accounting is materialized in the use of accruals for expenses and cash for revenues (Angélico 1995; Piscitelli et al. 1999; Giacomoni, 2008) which is not entirely correct as it can be seen below.

Corroborating the conclusion of Lima et al. (2009), it appears that the law is laconic about recognition and measurement criteria for Equity Variations; there are only partial criteria for the recognition of Budget Variations and nothing is assumed of those that occur outside the budget execution.

By Law, the prudence principle stipulates that revenues (income resources) are only recognized when they are delivered to those responsible for receiving them; meanwhile, as a rule other increases in equity are 
recognized when they occur, e.g. the registration of receivables updates, the natural creation of assets or liabilities elimination, close to the accrual basis.

As for expenses, Moura (2003:60) explains that they do not exactly observe either the accrual or the cash basis but have a specificity called the "budgeting accrual". The author explains that: "the Brazilian government expenditures are recognized as a result of budget execution, the generating act is not a necessary condition for recognizing expenses, but the budget commitment for the year to which it concerns.

As the positive changes, the other negative extra budgetary variations are also recognized when they occur, e.g. the consumption of inventories and the incorporation of debts. However, it is not valid to say that the accrual basis is followed because facts that would negatively influence the expenses of the period are not recognized, for example: depreciations of assets, provisions (for social benefits) or contingent liabilities, which are some components of the accrual basis (Moura, 2003).

What above mentioned describes the Brazilian accounting situation when this study as cried out. Presently, Brazil is moving to the IPSAS approach, since the Ordinance No. 184, 2008 of Ministry of Finance was issued. It establishes the guidelines to be observed in the public sector accounting about the procedures, practices, preparation and dissemination of financial statements in order to make them convergent with International Accounting Standards applied to the Public Sector. The first steps in this direction were taken in 2009 and is expected to conclude at the end of 2013, as provided for the Secretary of Treasury who leads this process.

\section{ACCOUNTABILITY IN HIGHER EDUCATION: MEASURING QUALITY}

Education is one of the most important services offered by the State due both its role in societal and individual development (Dewey, 1966) and also the size of the budget allocated. According to the Brazilian Federal Constitution, a minimum of $18 \%$ of tax revenue are employed to maintaining and developing education. In 2009, this equalled R\$ 30846 million (approximately U\$ 15500 million) according to Ministry of Finance data.

Moreover, with the adoption of NPM, Higher Education Institutions (HEIs) were asked to demonstrate the quality of their activities through comparable measures; this was a new factor in higher education as quality was understood to be implicit to this area until the 1990s (Harvey and Askling, 2003).

The need for accountability in public activities is not generally questioned but in education there is an extensive debate on how it should occur. The discussions range from how quality should be defined to what higher education is. Vlãsceanu et al. (2007:70) explain that:

Quality in higher education is a multi-dimensional, multi-level, and dynamic concept that relates to the contextual settings of an educational model, to the institutional mission and objectives, as well as to specific standards within a given system, institution, programme, or discipline. Quality may thus take different, sometimes conflicting, meanings depending on (i) the understanding of several interests related to different higher education stakeholders (e.g. students; universities; disciplines; the labour market; society; the government); (ii) its circumstances: inputs, processes, outputs, missions, objectives, etc.; (iii) the attributes or characteristics of the academic world merit evaluating; and (iv) the historical period in higher education development

For Miranda (2001), the current trend of models for quality performance and accountability has followed a business approach and it would be impossible to measure the effectiveness of an educational system based on these parameters.

Despite criticisms, performance-based accountability models were adopted in a number of countries, even affecting the institutions funding. This happened in the United States, United Kingdom, Finland, Germany, Sweden, Denmark, Holland and Austria (Alexander, 2000).

Concerning the design and use of performance indicators, Cave et al. (1997:25) stated that "higher education should be seen as a process that transforms inputs into outputs being itself part of a larger economic and social 
process." The time spent by students and academics, the current supplies, equipment and facilities are among the inputs highlighted by the authors who claim that outputs can be classified as teaching or research related.

Figure 1 illustrates the "productive" process at universities and its main inputs and outputs. 
Figure 1: Input - Output Evaluation Approach in Higher Education

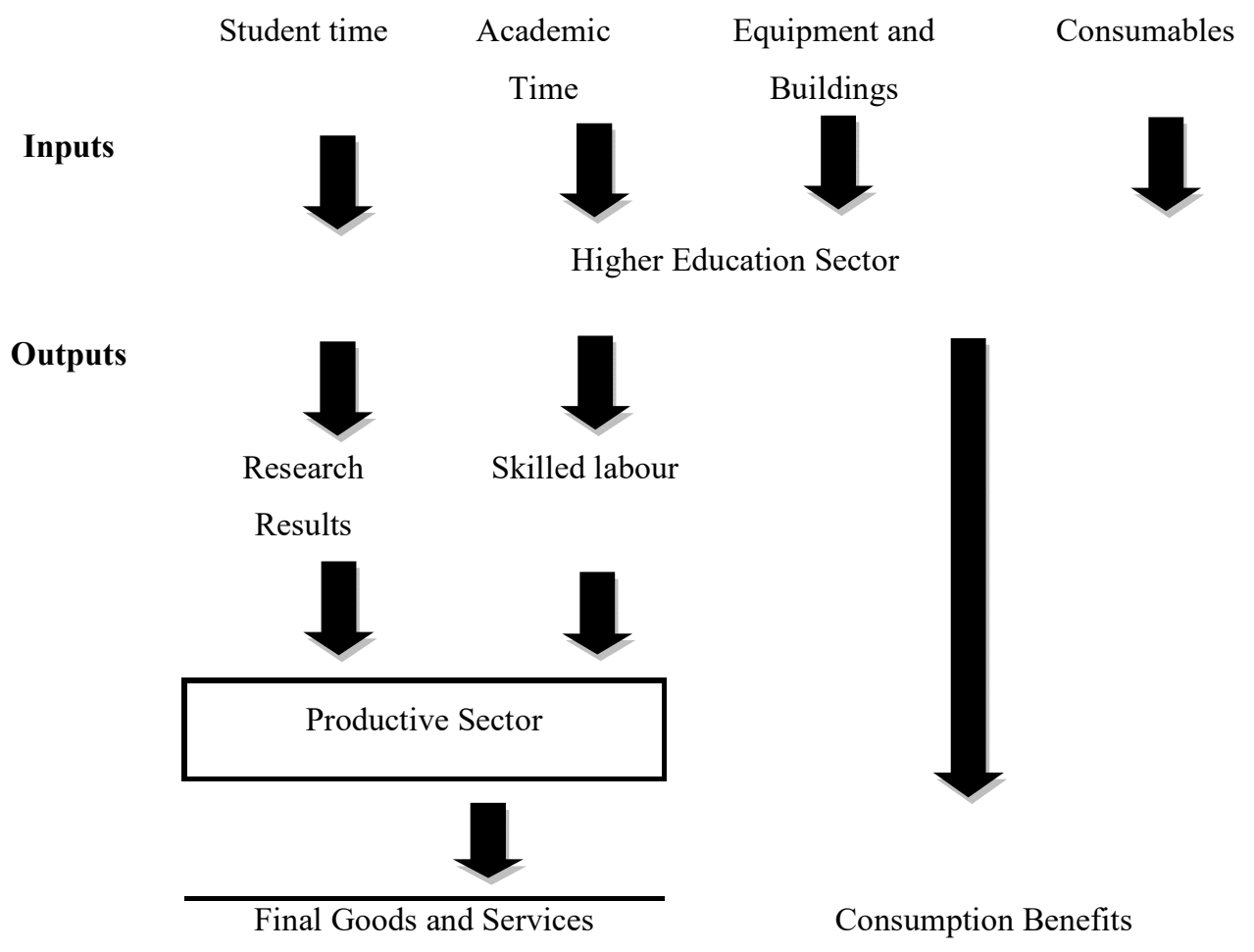

Source: Adapted from Cave et al. (1997)

\subsection{Evaluation of Higher Education in Brazil}

In Brazil, the evaluation system that had been planned in 1996 under the influence of NPM was reformulated in 2004 with the establishment of the National Assessment System of Higher Education - SINAES, by Law No. 10.861/2004. This System looks for evaluating institutions, courses and student performance (Martin, 2009).

In 2009 the Instituto Nacional de Estudos e Perquisas Educaionais Anísio Teixeira (National Institute of Educational Studies and Research Anísio Teixeira ) - INEP, under the Ministry of Education (MEC), began disseminating a new quality indicator for higher education institutions in Brazil, named the General Index of Courses (GIC). This considers the quality of undergraduate programs according to Preliminary Course Grade measurements and postgraduate (master's and doctorate) in line with the assessments made by the Coordination of Improvement of Higher Education Personnel (CAPES), also linked to the MEC.

This study adopts the GIC as the dependent variable measuring the quality of Higher Education Institutions (HEIs), because this index is based in students' performance calculated by National Exams and in academic production quality, as measuring output quality; it also considers the quality of inputs such as, teachers' degrees, infrastructure and the pedagogical organization of the HEIs (Fernandes et al., 2009).

The GIC is a weighted average of each institution's undergraduate and graduate courses and has two classifications: one by levels, that classifies institutions into five groups according to quality and a continuous classification that assigns a score from 0 to 500. The distribution of HEIs students between different courses evaluated at a range of education levels (undergraduate, masters and doctorate) is used to survey the concepts. 
Accordingly, the quality of the entity's outputs is an alternative measure for assessment in the public sector, once it reflects the society's perception of relevance about goods and services provided by HEI's. Although providing excellent goods and services depends on a chain that begins with investments in quality, the quality is perceived and valued by customers through the outputs (Coelho and Vilares, 2010).

\section{ANALYSIS OF THE RELATIONSHIP BETWEEN THE QUALITY INDEX, ACCOUNTING INFORMATION AND AUDIT FINDINGS}

This analysis seeks to answer the two research questions early formulated. About the first research question, it aims to determine whether the Financial Statements of the Brazilian federal public universities are generally useful to accountability from the point of view of performance management. The hypothesis formulated is: if accounting information is useful for evaluating management regarding outputs perspective, a relationship should be established, which gives accounting information some explanatory power concerning performance achieved by the HEIs.

One other hand, regarding the second question, this research intends to assess if there is some relationship between the findings of non-compliance in audits and the Brazilian Federal Universities performance.

\subsection{Research Method}

To achieve this research purposes, a model based on a multiple linear regression will be estimated, in order to obtain financial information that explains the performance of federal universities measured by GIC. The model aims to assess the predictability of accounting information in performance sets with variables that represent inputs in the university production process and also the presence of findings of audit exceptions or irregularities in the auditors' opinions.

\subsection{Data}

Several sources of data were accessed for this study. Financial Statements and audit certificates from the universities were granted by the Federal Internal Control Secretariat of the Office of Comptroller General of Brazil. Non-financial information about the degree courses were obtained through the Higher Education Census, conducted annually by INEP / MEC. As this provides data on its electronic website but without identifying the HEIs, this information was kindly provided by INEP for research purposes only, to enable data from various sources to be linked. The HEI evaluation by the GIC is also provided directly by INEP on its web site.

Master's and doctoral data were extracted directly from the System GeoCapes which provides online information about post-graduate programs supervised by Capes - Coordination for the Improvement of Higher Education on its web site.

\subsection{Universe Search}

The General Index of Courses (GIC) used in this study was published in 2009 and refers to 2007, it was first published and no significant differences were found in relation to later. In that year Brazil had 53 federal universities in operation; only 51 received positive evaluations by INEP / MEC. The Federal University of Vale do San Francisco, founded in 2002 but set up only in 2004, and the Federal University of ABC, formed in 2005 and installed in 2006, were both excluded.

The 51 universities included in the study, had a total of 667.519 students and consumed R\$ 17.920 million (U\$ 9.005 million) in 2007. Figures 2 to 5 present an overview of the universe. 
Figure 2 - Distribution of universities according to the

Figure 3 - Distribution of Universities according to number of students working time in years
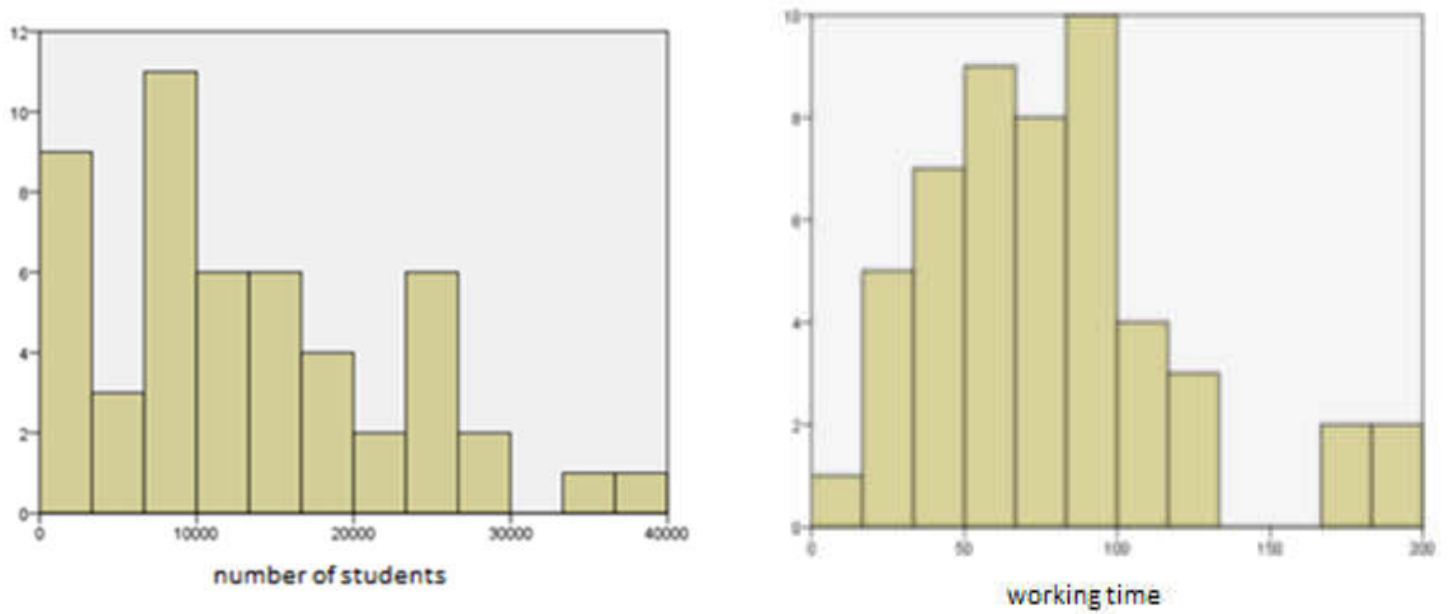

Figure 4 - Distribution of universities according to the budget accomplished in 2007

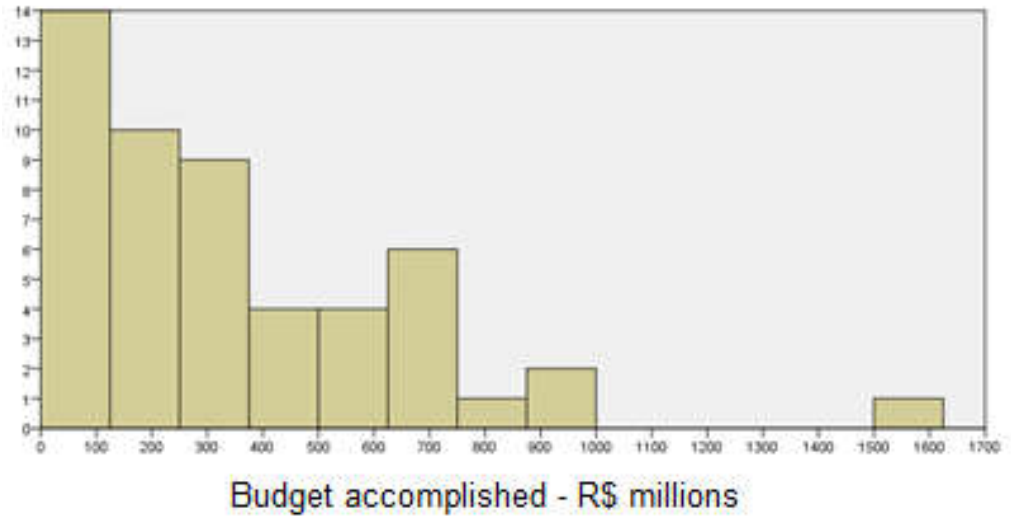


Figure 5 - Distribution of universities according to performance measured by the MEC

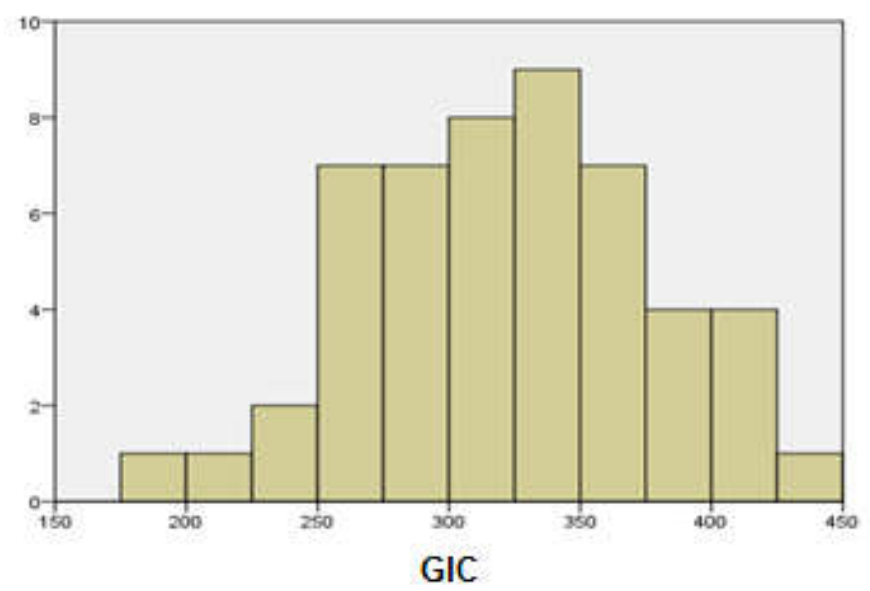

\subsection{Specification and Models Analysis}

Ross et al. (2001) argue that the goal of management is to create value for the stockholders, so that this would be the main measure for accountability in private companies. Thus, according to Moreira (2009), models designed to evaluate the predictive power of accounting information in financial accounting seek to relate the price or profitability of company shares with accounting variables related to their performance; these models have formulas such as

$$
P_{j t}=\alpha+\beta X_{j t}+\varepsilon_{j t}
$$

in which $\mathrm{P}$ is the price or profitability, $\mathrm{X}$ is one or more components of profitability and $\beta$ is the coefficient of response of prices to income (ERC earnings response coefficient).

The Ohlson model (1995), or its variations, is the model adopted in the accounting studies including those on value relevance and it relates the value, not only with outcome variables, but presents three kinds of variables in a model of type

$$
V_{t}=b_{t}+\alpha_{1} x_{t}^{a}+\alpha_{2} v_{t}
$$

where the dependent variable $\left(V_{t}\right)$ is the company's intrinsic value given by the share price, and explanatory variables are: $b_{t}$ is the book value of the company's equity capital which is a stock measure; $x^{a}{ }_{t}$, is the current profitability, which is a flow measurement, and $v_{t}$ considers "other information" affecting the prediction of future profitability.

In theory, this kind of model could not fit the public sector, once the dependent variable generally used - the value of the entity measured at market price, doesn't exist on the public sector. However, this study is based on the assumption that the dynamics sustaining these models can be adapted to the public sector reality because in Ohlson's model the value is a function of stock variable, a flow variable and is also affected by "other information" such as quality of management. On HEIs the value (understood as quality) is a function of stocks variable (infrastructure), flow variable (academic time, consumables, etc) and is also affected by "other information" as quality of management, pedagogical approach and others as described by Cave et al. (1997).

\subsubsection{Definition of Variables}

The model to be estimated is inspired on Ohlson (1995) in relation to flows and stocks and also considering "other information" (in this case compliance of managers) to explain the dependent variable. 
The form provided for the first model is:

$$
G I C_{u}=\beta_{1}+\beta_{2} C E_{u}+\beta_{3} O A_{u}+\beta_{4} R_{u}+\varepsilon
$$

In which:

$\mathrm{GIC}_{U}$ - index of university courses $\mathrm{u}$;

$\mathrm{CE}_{\Downarrow}$ - Current Expense per student in the university $\mathrm{u}$;

$\mathrm{OA}_{U}$ - Operating Assets per student in the university $\mathrm{u}$;

$\mathrm{R}_{\mathrm{u}}$ - presence of reservations or irregularities in the audit opinion of the university $\mathrm{u}$;

$\varepsilon$ - error.

The definition of the GIC (General Index of Courses) as the dependent variable is a consequence of the absence of an objective direct measure in Brazilian public sector to evaluate the value of equity. In public companies this is measured through its share price. It must be noticed that the share price is not an absolute measure because it only reflects the value of the company to minority investors. In cases of acquisition of relevant positions, other factors influence the value and the market price is no longer the best indicator of company value (Higgins, 2007).

In public entities, it is not practicable to discuss perceived value from a merely financial perspective as public services are subsidized, and even when there is payment, prices do not result from the user's value perception. Even if obstacles arise in the private sector, a measure of value can be reached and is expressed in monetary terms; however, evaluation in the public sector does not always manifest itself so clearly and objectively. As Moore (1996) explains, the value generated by the public sector will depend on society's perception of the importance of the goods or services provided and that perception is not translated into monetary terms as in private companies.

The independent variables are derived from the Cave et al. (1997) framework, which identifies four basic groups of inputs in universities: Students Time; Academic Time, Equipment and Buildings, and Consumables. No specific variable will be adopted for students because they are not directly reflected in the financial statements; in addition, as explained Fernandes et al. (2009), on average, the best students choose Brazilian public universities due their quality and also for cost reasons. This assumption of equilibrium among the students of different HEIs distances them from the explanation of the university performance.

Financial variables in this study will always be in formula of averages per student so that comparisons can be made between entities and also interpreting the dependent variable which, as mentioned above, consists of a weighted average per student.

The variable $\mathrm{CE}_{U}$ - current expenses per student, will be adopted to represent the Academics' salaries and benefits and the consumables costs. This definition is justified because it covers all the operation expenses of university funding. Similar to the Ohlson model (1995), this variable represents the flows; as public universities are not profit oriented, what really affects the "production" process, and therefore quality, is the amount of resources applied rather than the amount received or even the difference between them. As teachers' salaries in Brazil are similar in public universities and are mainly based on title and also on scientific productivity, this variable also reflects the qualifications ability at the HEI disposal.

$\mathrm{OA}_{U}$ - Operating Assets per student is the variable illustrating equipment and buildings (measures of stocks), based on the Balance Sheet.

The third variable - $R_{u}$ - is a dummy variable and indicates whether there are reservations in the audit opinion (compliance) issued by the central organ of federal executive internal control department; Value 1 (one) is assumed when there are qualified audit opinions (reservations or irregularities) and value 0 (zero) for clean opinions. This variable is set as analogous to the "other information", due the definition that an entity must 
achieves its objectives in three dimensions: operational, financial reporting and compliance with laws and regulations (COSO, 1992).

\subsubsection{Model Estimation and Analysis}

The model will be estimated by applying the Method of Ordinary Least Squares (OLS), under which the variance of the estimators is minimal among the centred linear estimators, so these are the most efficient estimators (BLUE - Best Linear Unbiased estimators) if the following conditions are observed (Gujarati, 2000):

- The relationship between the dependent and explanatory variables is linear;

- The explanatory variables are non-stochastic;

- There is no perfect linear relationships between explanatory variables;

- $\quad$ Expected value of errors $=0$;

- The errors are normally distributed;

- The variance of the errors is constant (homoscedasticity);

- There is no autocorrelation between the errors;

- The covariance between the dependent variable and the errors $=0$;

- The number of observations is larger than the parameters to be estimated;

- The values of the explanatory variables cannot all be equal;

- $\quad$ The model must be well specified.

For all statistical tests to be carried out, the confidence interval considered in the tests is $95 \%$, which means establishing the statistical significance at $5 \%(\alpha=0.05)$.

The relationship curve between the dependent and explanatory variables in the graph confirms that their relationship is closer to a linear logarithmic function, as in Figures 6 and 7. According to Curto (2006:96), in these cases, "you can transform some or all variables to reduce the problem to linear form."

Figure 6 - Relationship between OA and GIC

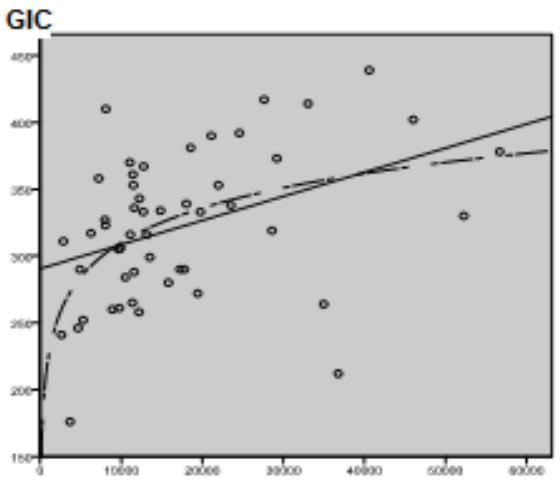

Operating Assets per student
Figure 7 - Relationship between CE and GIC

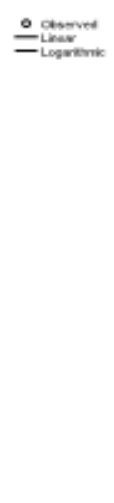

GIC

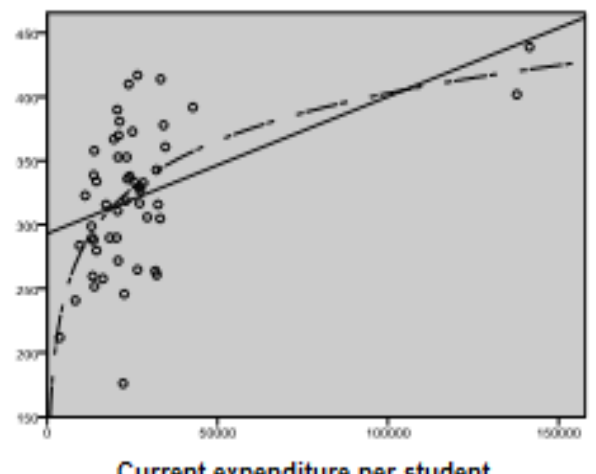

는

Thus, a linear-log model will be adopted where the dependent variable does not change, but the independent variable appears in logarithmic form. So the estimated model takes the form:

$$
I G C_{u}=\beta_{1}+\beta_{2} \ln C E_{u}+\beta_{3} \ln O A_{u}+\beta_{4} R_{u}+\mathrm{a}
$$


The estimated coefficients for Model (4) by the method of OLS are listed in Table 1.

Table 1: Estimated Coefficients for Model (4)

\begin{tabular}{lllll}
\hline \hline & Coefficient & Std. Error & t-Statistic & Prob. \\
\hline \hline $\ln C E$ & 42.41072 & 11.83998 & 3.581993 & 0.0008 \\
$\ln O A$ & 24.48960 & 9.605084 & 2.549649 & 0.0141 \\
$R$ & 11.32428 & 26.61555 & 0.425476 & 0.6724 \\
$\mathrm{C}$ & -346.2765 & 122.2242 & -2.833126 & 0.0068 \\
\hline \hline & 0.393527 & Mean dependent var & 321.8039 \\
R-squared & 0.354816 & S.D. dependent var & 55.66903 \\
Adjusted R-squared & 44.71522 & Akaike info criterion & 10.51369 \\
S.E. of regression & 93974.20 & Schwarz criterion & 10.66521 \\
Sum squared resid & -264.0991 & Hannan-Quinn criter. & 10.57159 \\
Log likelihood & 10.16576 & Durbin-Watson stat & 1.962231 \\
F-statistic & 0.000028 & & & \\
Prob(F-statistic) & & & \\
\hline \hline
\end{tabular}

Given the normality of errors ${ }^{1}$, it is possible to assess the general validity from the model using the $\mathrm{F}$ test with null hypothesis (H0) that all the estimated coefficients for the model are zero. As in the estimated model, the probability associated with the F test (Table 1$)$ is below the significance level $(\alpha=0.05), \mathrm{H} 0$ is rejected and it might be concluded that the model has general validity.

The statistics and associated probabilities for t test (Table 1), which has the null hypothesis (H0) that the estimated coefficient is zero, show that for a significance level of $5 \%(\alpha=0.05) \mathrm{H} 0$ for the estimated coefficients, regarding $\operatorname{lnCE}$ and InOA, must not be rejected, although $\mathrm{H} 0$ for the estimated coefficient regarding variable $\mathrm{R}$ is rejected; this means that the estimated coefficient can assume the value 0 and is therefore unable to express the effect of this variable in explaining the dependent variable, suggesting its exclusion from the model.

The exclusion of variable $\mathrm{R}$ from the model confirms that it cannot be stated that the findings of noncompliance in audits regularly have statistical significance in explaining the performance of federal universities.

Some restriction on the audit opinion was observed in $94 \%$ of universities which makes the parameter almost uniform, thus excluding the capacity to explain the performance differences between universities. The causes and effects of irregularities / reservations found in almost all the universities allows further study to determine whether they arise from the complexity of rules, from the author detailing or from fragile management. Regarding the nature of reservations and irregularities found, some specific categories affecting the entity's performance are identified.

Alternatively, it was evaluated the effect only of events classified as severe irregularities ( $\left.\mathrm{R}^{\prime}\right)$. Consequently the values of dummy variables were replaced, the value 1 was assumed for universities with the opinions of irregularity and 0 for the others. The conclusions remained unchanged as can be seen from Table 2 showing that the rejection of $\mathrm{H} 0$ in the t-test for R'. Then both the variable $\mathrm{R}$ and $\mathrm{R}$ ' will be dropped from the model.

\footnotetext{
${ }^{1}$ The hypothesis on the normality of errors and their expected value is zero has been confirmed by descriptive statistics and statistical tests such as the Jarque-Bera and Kolmogorov-Smirnov test.
} 
Table 2: Estimated Coefficients for Model (4) with changes in R.

\begin{tabular}{lllll}
\hline \hline & $\mathrm{B}$ & Std. Error & $\mathrm{t}$ & Sig. \\
\hline \hline (Constant) & -336.148 & 120.459 & -2.791 & .008 \\
$\ln D c$ & 42.360 & 11.972 & 3.538 & .001 \\
$\ln A c$ & 24.606 & 9.690 & 2.539 & .014 \\
$R^{\prime}$ & -1.818 & 32.703 & -.056 & $\mathbf{. 9 5 6}$ \\
\hline \hline
\end{tabular}

These findings demonstrate that the approach of audits performed by the Internal Control System do not cooperate in the evaluation entities regarding its purpose.

By discarding the variable $\mathrm{R}$, the model to be estimated is the following:

$$
G i C_{u}=\hat{\mathrm{a}}_{1}+\hat{\mathrm{a}}_{2} \ln C E_{u}+\hat{\mathrm{a}}_{3} \ln O A_{u}+\mathrm{a}
$$

The estimated coefficients for Model (5), through the OLS method are listed in Table 3.

Table 3 - Estimated Coefficients for Model (5)

\begin{tabular}{lllcc}
\hline \hline & Coefficient & Std. Error & t-Statistic & Prob. \\
\hline \hline $\ln C E$ & 42.45001 & 11.73818 & 3.616405 & $\mathbf{0 . 0 0 0 7}$ \\
$\ln O A$ & 24.54247 & 9.521994 & 2.577451 & $\mathbf{0 . 0 1 3 1}$ \\
$\mathrm{C}$ & -336.5150 & 119.0231 & -2.827309 & 0.0068 \\
\hline \hline R-squared & 0.391191 & Mean dependent var & 321.8039 \\
Adjusted R-squared & 0.365824 & S.D. dependent var & 55.66903 \\
S.E. of regression & 44.33212 & Akaike info criterion & 10.47832 \\
Sum squared resid & 94336.16 & Schwarz criterion & 10.59196 \\
Log likelihood & -264.1971 & Hannan-Quinn criter. & 10.52174 \\
F-statistic & 15.42125 & Durbin-Watson stat & 1.976545 \\
Prob(F-statistic) & $\mathbf{0 . 0 0 0 0 0 7}$ & & \\
\hline \hline
\end{tabular}

It thus appears that the estimated model (5) does not go against any of the basic assumptions ${ }^{2}$ and is therefore useful for inferences. Inserting the estimated coefficients (Table 3) in the model (5), it is designed model (6) that describes the behaviour of the GIC in terms of CE and PA, as follows:

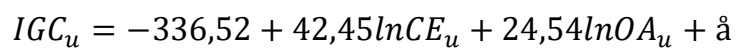

Comparisons could not be made with any other studies of value relevance in the public sector because, as mentioned in the explanation of the variables, public sector entities have no common parameters unlike the private sector which has the share price. Despite these limitations and also the weaknesses identified in the accounting information of the Brazilian public sector, it appears that accounting information has a material

\footnotetext{
${ }^{2}$ The hypothesis of Multicollinearity is excluded by verifying the correlation between the explanatory variables of Tolerance measures (Tol) and the Variance Inflation Factor (VIF).

The hypothesis of homoscedasticity is not excluded by White Test.

The hypothesis of first-order self-correlation is excluded according to Durbin-Watson test.
} 
interest ( $2=39 \%$ ) in explaining the behaviour of quality measurement in the universities surveyed. The value found for R2 is nearby to measures of value relevance of financial accounting observed in the late 50th and also in the 70s as described by Brown et al. (1999). It is therefore expected that an improvement in quality of accounting information would give outputs a greater explanatory power.

The validity of the model also points out to confirm that accounting information is a useful tool for stakeholders and may be used for both decision-making as an accountability tool for service users and the society in general. So the disclosure of accounting information and further analysis of performance based on this information fulfil their monitoring role on managers.

It was also observed in the model that the estimated coefficients for $\operatorname{lnCE}$ are positive, i.e., it is expected that when the values of CE or OA are incremented, the GIC will respond in the same direction; it should be noted however that, as shown by Short (2006: 82), the marginal effect determined by a logarithmic relationship will be $\frac{\hat{a}_{i}}{X_{i}}$

In practice, the model suggests that for entities where the value of the infrastructure and the costs per student are low, a moderate increase in the values of these variables will result in a good response to the quality index; on the other hand, in cases where such values are sufficiently high, only large increases in average per student of infrastructure and costs expenditures will result in a noticeable response in the quality index. Mungaray et al. (2010) show that in Mexico, federal policy of extraordinary public financing toward HEI's have generated positive impacts on the process of institution-building and institutional reduce inequalities between them.

It also appears that the model suggests current expenses have a greater influence on the performance than infrastructure expenditures. This is consistent with the findings of Nagadevara and Tara (2007), showing that are the "soft" issues, e.g. highly qualified academics, access to the latest scientific publications and participation in conferences and seminars, that distinguish institutions of higher quality and not "hard" aspects linked to infrastructure. From the financial point of view, the current expenses reflect these "soft" aspects. There is also consistency with the Adelabu and Akinwumi (2008) findings, showing that a small level of funding has a negative multiplier effect on the universities quality; these authors emphasize that little resources allocation makes impossible to obtain good teachers and incomes they can operate.

These analysis findings are also especially useful for control agencies and higher education policy makers. Performance audits can be directed to identify the causes of low incomes in some institutions vis-à-vis the outcomes of others in similar conditions. Performance relating to resources can also be used as a criterion to select units to be audited, considering that the internal and external control bodies have limited means, also suggesting a reflection on the audit approach.

\section{CONCLUSIONS}

This study framework is supported by accountability role in democratic societies and the changes influenced by New Public Management in accountability and consequently in the public sector accounting information systems.

It aims evaluating the usefulness of accounting information as well as the findings of non compliance in the opinions of audits conducted by Internal Control System in explaining the quality of 51 Brazilian federal universities, using data from the General Index of Courses published in 2007.

From the empirical analysis it was possibly to answer to the research questions previously formulated.

About the first one:

Is the accounting information provided by universities useful to the accountability process in terms of performance and does it helps to explain the performance of the Brazilian Federal Universities in the quality ratings they are submitted? 
This study demonstrates that the accounting information, particularly the variables of Current Expenditures per student and Permanent Assets per student, has significant explanatory power on the quality index $\left(\mathrm{R}^{2}\right.$ $0.391)$.

As there are no related studies in the public accounting field, this becomes an initial benchmark for future studies. The validity of the model also points out to confirm that accounting information is a useful tool for stakeholders and can be used for both mangers decision-making as an accountability instrument for public services users and also the society in general.

The specified model also reveals that both variables are positively correlated with the quality index and that flow variables (Current Expenditure) have greater impact than the stock variables (Permanent Assets). Thus, despite the undeniable need for infrastructure, the issues related to current activities are most relevant. This finding is consistent with Nagadevara and Tara (2007) study conclusions, accordingly to institutions are distinguished not by the higher quality of "hard" aspects linked to infrastructure, but by "soft" issues linked to current operations, like high academic qualifications, access to the latest scientific publications, etc..

Another important issue is the logarithmic relationship between the dependent variable and the explanatory variables reflected in the log-linear model adopted. It follows that the resulting function is growing but at decreasing rates, which means that in institutions with low values for current expenditures and permanent assets, moderate variations in these values produce a significant effect on the quality index. Furthermore, large variations in institutions which already have high values will produce a small effect on the quality index.

Regarding the second research question:

Do the findings of non-compliance in audits influence the performance of the Brazilian Federal Universities in the quality ratings that are submitted?

The empirical data analysis shows that restrictions on audit opinions are not statistically significant in explaining the quality measured by GiC. It was found that $94 \%$ of HEIs had some kind of reservations or irregularity in their opinions. After verifying if only the most serious occurrences (irregularities) were significant in explaining the performance, the previous findings were similar.

As seen, the Internal Audit Manual of Federal Executive Branch defines that a comprehensive process should support the audit opinion, including performance aspects. The empirical evidence that qualifications in those opinions are not relevant to explain the performance of universities points out to the diminutive relevance of the qualifications themselves. The existence of qualifications in almost all audit opinions and their great disparity reduces their ability as an appropriate tool to assess management performance of the Brazilian federal universities.

This research main contribution is to provide knowledge on relevant aspects of Public Sector Accounting in itself and also its application in higher education sector in Brazil. It confirms the importance of accounting to accountability regarding both official institutions and other stakeholders. The findings may assist as criteria for formulating public policies on resource allocation in education, and also contribute to improve auditing systems in the Internal and External Control of the Education Sector.

This study intends to contribute too as a starting point to future researches to verify value relevance changes in the accounting informative outputs, manly considering the new public sector accounting reform in Brazil started in 2011, following the international harmonization approach. 


\section{BIBLIOGRAPHIC REFERENCES}

Adelabu, M. A., and F. S Akinwumi (2008), "Factors Affecting Academic Quality in Nigerian Universities". Journal of the World Universities Forum, 1(5), pp. 47-61.

Alexander, F. K. (2000), "The Changing Face of Accountability: Monitoring and Assessing Institutional Performance in Higher Education". The Journal of Higher Education, 71 (4), pp. 411-431.

Angélico, J. (1995), Contabilidade Pública, 8nd edn. Atlas, São Paulo.

Barzelay, M. (1996). "Performance auditing and the New Public Management: changing roles and strategies of central audit institutions", in PUMA. Performance auditing and the modernisation of Government, Paris: OECD, pp. 15-56.

Bresser-Pereira, L. C. (2000), "Reforma Gerencial do Estado de 1995”, Revista de Administração Pública, 34 (4), pp. 55-72.

Cave, M., S. Hanney and M. Kogan (1997), The Use of Performance Indicators in Higher Education, Jessica Kingsley Publishers, London.

Christensen, T and P. Lægreid (2005), "El estado fragmentado: los retos de combinar eficiencia, normas institucionales y democracia”, Gestión y Política Pública, XIV (3), pp. 557-598.

CLAD - Centro Latinoamericano de Administración para el Desarrollo (1998), Uma Nova Gestão Pública para a América Latina, CLAD, Caracas.

Coelho, P. S. and M. J. Vilares (2010), "Measuring the return of quality investments", Total Quality Management \& Business Excellence, 21(1), pp. 21 - 42.

COSO - Committe of Sponsoring Organizations of the Treadway Commission (1992), Internal Control Integrated Framework, 2nd edn. COSO, New York.

Curto, J. D. (2006), Métodos Estatísticos e Econométricos: aplicações em Finanças e Contabilidade, Mimeo.

Dewey, J. (1966), Democracy and education: An introduction to the philosophy of education. Free Press, New York.

Fernandes, R., Pazello, E. T., Leitão, T. M. S. P. and Moriconi, G. M. (2009), Avaliação de Cursos na Educação Superior: a função e a mecânica do Conceito Preliminar de Curso, INEP., Brasília.

Giacomoni, J., (2008), Orçamento Público, 14nd edn. Atlas, São Paulo.

Gujarati, D. N. (2000), Econometria Básica. 3rd edn, Pearson Makron Books, São Paulo.

Harvey, L and H. Askling (2003), Quality in higher education, in Begg, R (Ed.), The Dialogue between Higher Education Research and Practice, 69-83, Kluwer Academic Publishers, Amsterdam.

Higgins, R.C. (2007), Análise para Administração Financeira, 8th edn McGraw-Hill, Rio de Janeiro.

Hood, C. (1995), "The "New Public Management" in the 1980s: Variations on Theme", Accounting Organizations and Society, 20(2-3), pp. 93-109.

IPSASB - International Public Sector Accounting Standards Board (2009), Handbook of International Public Sector Accounting Pronouncements V2. International Federation of Accountants, New York. 
Jansen, E. P. (2008), "New Public Management: perspectives on performance and the use of performance information", Financial Accountability \& Management, 24(2), pp. 169-190.

Jesus, M. A. (2010), A Contabilidade Pública e a Contabilidade Nacional: Principais Divergências e Implicações no Défice Público em Portugal, Textos Universitários de Ciências Sociais e Humanas, Fundação Calouste Gulbenkian, Fundação para a Ciência e Tecnologia, Agosto de 2010.

Lapsley, I. (2008), “The NPM agenda: back to the future”, Financial Accountability \& Management, 24 (1), pp. 77-96.

Lee, R.D., R. Johnson and P. Joyce, (2004), Public Budgeting Systems, 7th edn. Jones \& Bartlett Publishers, Sudbury.

Lima, D. V., C. M. Santana and M. A. Guedes (2009), "As Normas Brasileiras de Contabilidade aplicadas ao setor público e a legislação contábil pública brasileira: uma análise comparativa à luz da teoria contábil”. Contabilidade, Gestão e Governança, 12 (2), pp. 15-23.

Martin, M. (2009), “On the relationship of external quality assurance and equity: Can they converge on national policy agendas?, Quality in Higher Education, 15 (3), pp. 251-262.

Ministério da Fazenda (2001), Manual do Sistema de Controlo Interno do Poder Executivo Federal, www.cgu.gov.br/AreaAuditoriaFiscalizacao/Arquivos/AuditoriasAnuaisEPrestContas/IN 01_06042001.pdf

Ministério da Fazenda (2009), Relatório resumido da execução orçamentária do governo federal e outros demonstrativos relativo ao mês de Dezembro,

www.stn.fazenda.gov.br/hp/downloads/lei_responsabilidade/RROdez2009.pdf

Miranda, A. V. (2001), “Educación superior de calidad para el siglo XXI”, Educación, 25(1), pp. 9-17.

Moore, M. H. (1996), Creating public value: strategic management in government. Harvard University, Cambridge.

Moreira, J. A. C., (2009), Investigação em Contabilidade Financeira: três contribuições seminais, in Major, M. J. and Vieira, R. Contabilidade e Controlo de Gestão: Teoria, Metodologia e Prática. Escolar Editora, Lisboa.

Moura, R. A. (2003), Princípios Contábeis Aplicados à Contabilidade Governamental: uma abordagem comparativa Brasil-Estados Unidos. Dissertação de Mestrado, Programa Multiinstitucional e Inter-Regional de Pós-Graduação em Ciências Contábeis da Universidade de Brasília, da Universidade Federal da Paraíba, da Universidade Federal de Pernambuco e da Universidade Federal do Rio Grande do Norte.

Mungaray, A. , M. T. Ocegueda, P. Moctezuma y J. M. Ocegueda (2010), "Financiamiento de la equidad entre las universidades públicas estatales de México: 2001-2005”, Gestión y Política Pública, XIX (2), 2010, pp. 263-310.

Nagadevara, V. and N. S. Tara (2007), "Factors Influencing Quality of Technical Education In India - A Study Of Technical Institutions In Karnataka”, International Journal of Business Research, 7 (2), pp. 205-212.

Niyama, J. K. and C. A. T. Silva (2008), Teoria da Contabilidade, Atlas, São Paulo.

Nunes, S. P. P. (2007), “A Contabilidade e a Governança Públicas e a Lei de Responsabilidade Fiscal”, Anais do I Seminário Internacional de Contabilidade Pública, pp. 103-107, Novembro, Brasília,

Ohlson, J.A. (1995), "Earnings, book values, and dividends in equity valuation", Contemporary Accounting Research, 11(2), pp. 661-687. 
Piscitelli, R. B., M. Z. F. Timbó and M. B. Rosa (1999) Contabilidade pública: uma abordagem da administração financeira pública, 6 end, rev., ampliada e atualizada, Atlas, São Paulo.

Porter, G. A. and C.L. Norton (2009), Financial Accounting: The Impact on Decision Makers, Mason, $\mathrm{OH}$ :Cengage Learning.

Ross, S A., R. Westerfield and B. D. Jordan (2001), Essentials of corporate finance, 3nd edn. McGraw-Hill, Boston.

Sarker, A. E. (2009), "The New Mode of Public Governance and Public Accountability in Developing Countries: An Analysis with Particular Reference to Bangladesh", International Journal of Public Administration, 32(13), pp. 1101-1123.

Schedler, A. (1999), Conceptualizing Accountability in New Democracies, in Schedler, A., L. Diamond e Plattner, M. (org.) The Self Restraining State: Power and Accountability in New Democracies, Lynne Rienner Publishers, London.

Sharkansky, I. (2007), “Israel's auditor as policy-maker”, Public Administration, 66 (1), pp. 77-89.

Ter Bogt, H. J. (2008), "Management Accounting change and New Public Management in local government: a reassessment of ambitions and results - an institutionalist approach to accounting change in the Dutch public sector", Financial Accountability \& Management, 24(3), 209-241.

Vlãsceanu, L., L. Grünberg, and D. Pârlea (2007), Quality Assurance and Accreditation: a glossary of basic terms and definitions, 2nd, Unesco, Bucharest.

Weffort, E. F. J. (2005), O Brasil e a Harmonização Contábil Internacional: Influências dos sistemas jurídicos e educacionais, da cultura e do mercado, Tese de Doutorado, Departamento de Contabilidade e Atuária, Universidade de São Paulo, Atlas, São Paulo. 